\title{
Gastroparesis and Dumping Syndrome: Current Concepts and Management
}

\author{
Stephan R. Vavricka ${ }^{1,2, *}$ and Thomas Greuter ${ }^{2}$ \\ Center of Gastroenterology and Hepatology, CH-8048 Zurich, Switzerland \\ 2 Department of Gastroenterology and Hepatology, University Hospital Zurich, CH-8091 Zurich, Switzerland \\ * Correspondence: stephan.vavricka@hin.ch
}

Received: 21 June 2019; Accepted: 23 July 2019; Published: 29 July 2019

\begin{abstract}
Gastroparesis and dumping syndrome both evolve from a disturbed gastric emptying mechanism. Although gastroparesis results from delayed gastric emptying and dumping syndrome from accelerated emptying of the stomach, the two entities share several similarities among which are an underestimated prevalence, considerable impairment of quality of life, the need for a multidisciplinary team setting, and a step-up treatment approach. In the following review, we will present an overview of the most important clinical aspects of gastroparesis and dumping syndrome including epidemiology, pathophysiology, presentation, and diagnostics. Finally, we highlight promising therapeutic options that might be available in the future.
\end{abstract}

Keywords: gastroparesis; dumping syndrome; pathophysiology; clinical presentation; treatment

\section{Introduction}

Gastroparesis and dumping syndrome both evolve from a disturbed gastric emptying mechanism. While gastroparesis results from significantly delayed gastric emptying, dumping syndrome is a consequence of increased flux of food into the small bowel [1,2]. The two entities share several important similarities: (i) gastroparesis and dumping syndrome are frequent, but also frequently overlooked; (ii) they affect patient's quality of life considerably due to possibly debilitating symptoms; (iii) patients should be taken care of within a multidisciplinary team setting; and (iv) treatment should follow a step-up approach from dietary modifications and patient education to pharmacological interventions and, finally, surgical procedures and/or enteral feeding. Most importantly, the two diagnoses have to be considered by one of the treating specialists, regardless of whether this is the endocrinologist, nutritional specialist or gastroenterologist, when symptoms are present. Pre-test probability based on comorbidities (such as diabetes in case of gastroparesis or surgical history for dumping syndrome) together with the presence of typical symptoms should lead to a high degree of clinical suspicion. However, for both disorders, diagnostic evaluations should follow in order to confirm the diagnosis before initiation of treatment. Firstly, because treatment options might be invasive and require proper diagnostic evaluations beforehand. Secondly, several differential diagnoses might show a similar presentation. Such diagnoses are peptic ulcer disease, gastric cancer, celiac disease, abdominal angina for gastroparesis, anastomotic ulcers, internal herniation and gallbladder disease for early dumping syndrome and insulinoma, surreptitious use of glucose-lowering medication for late dumping [2-5]. In the following review, we will present an overview of the most important clinical aspects of gastroparesis and dumping syndrome including epidemiology, pathophysiology, presentation, diagnostics and treatment. Finally, we highlight promising therapeutic options that might be available in the future. 


\section{Definitions and Epidemiology}

Gastroparesis and dumping syndrome are frequent, but their prevalence and incidence vary depending on definitions and studied populations. Therefore, heterogenous results have been reported in the literature.

\subsection{Gastroparesis}

Gastroparesis is a syndrome characterized by an objectively delayed gastric emptying in the absence of a mechanical gastric outlet obstruction and the presence of cardinal symptoms such as early satiety, postprandial fullness and nausea-vomiting [6]. The prevalence of gastroparesis in the general population is uncertain. A wide range in different at-risk populations has been reported. In addition, gastroparesis is likely significantly under diagnosed. While an epidemiological study from Olmsted county revealed a prevalence of 24.2/100,000 for definite gastroparesis and 50.5/100,000 for definite, probable or possible gastroparesis [7], prevalence might be as high as $1.8 \%$ [8]. Patients with type 1 diabetes are at particular risk. Here, 10-year incidence rates of $5.2 \%$ have been reported (in contrast to a rate of $1 \%$ for type 2 diabetes and $0.2 \%$ for non-diabetic patients [9]. Other studies demonstrate even higher rates for diabetics with $58 \%$ for type 1 and 30\% for type 2 [10,11]. However, most of the performed studies have a considerable selection bias with inclusion of patients from tertiary referral centers only. Still, there might be a large proportion of undetected gastroparesis patients, because either the patient does not seek medical attention or the treating doctors are reluctant to evaluate symptoms and/or further diagnostics. The incidence of postsurgical gastroparesis after gastrectomy is approximately $0.4 \%$ to $5.0 \%$ [12]. Overall, the incidence of gastroparesis after surgery depends on the surgical procedure and the surgical site. In the early postoperative period after pylorus-preserving pancreatoduodenectomy, postsurgical gastroparesis occurs in up to $20 \%$ to $50 \%$ of patients [12]. In one study, $67 \%$ of patients who underwent pancreatic cancer cryoablation were found to suffer from gastroparesis [13]. There seems to be a gender-specific differences with women accounting for up to $70 \%$ of the affected population. Interestingly, elderly patients ( $>65$ years old) are at particular risk [14].

\subsection{Dumping Syndrome}

Dumping syndrome is a frequently encountered postsurgical complication that can be divided into an early and late subtype [2]. Alterations in gastric anatomy after esophageal, gastric and bariatric surgery result in rapid passage of food into the small intestine, which leads to early gastrointestinal and vasomotor symptoms (within $1 \mathrm{~h}$ ) and late hypoglycemia ( 1 to $3 \mathrm{~h}$ after meal ingestion) $[15,16]$. Reliable population-based prevalence data for dumping syndrome are still lacking. As of yet, the frequency of postsurgical dumping syndrome is estimated at $25 \%-50 \%$ with 5 to $10 \%$ of patients experiencing a severe disabling form [17]. These rates vary depending on type of surgery prodecure [2]. While $20 \%$ of patients suffer from symptoms of dumping syndrome after vagotomy and pyloroplasty, these rates rise to $40 \%$ after Roux-en-Y bypass and sleeve gastrectomy, and peak at $50 \%$ after esophagectomy [18-22]. The incidence and prevalence of dumping syndrome has been increasing due to the current obesity epidemics and the consecutive climb in gastric bypass surgeries [23]. Early dumping represents the most common type, while isolated late dumping is observed in only $25 \%$ [2,22]. Due to considerable overlap in clinical presentation it is, however, sometimes difficult to differentiate between the two and co-occurrence is frequently encountered.

\section{Pathophysiology and Clinical Presentation}

The occurrence of cardinal symptoms after ingestion of a meal in a patient with high pre-test probability should rise suspicion for the presence of gastroparesis or dumping syndrome. The symptoms per se are rather non-specific and might occur with many other diseases. However, the existence of risk factors such as diabetes for gastroparesis or bariatric surgery for dumping makes the diagnoses more likely (Tables 1 and 2). 


\subsection{Gastroparesis}

Several aspects contribute to a delayed gastric emptying in gastroparesis patients. Among these are extrinsic denervation of the stomach, impaired inhibitory input to smooth muscles due to loss of nitric oxide in enteric nerves, loss of interstitial cells of Cajal (ICC, "pacemaker cells), smooth muscle atrophy and altered function of immune cells [1]. ICC generate electrical slow waves in the stomach, and disrupted ICC networks and gastric dysrhythmias have been associated with gastroparesis [24]. For details see Figure 1. The most frequent etiologies are diabetes and surgery [25]. In a high proportion of patients, the underlying cause remains unknown (so called idiopathic gastroparesis) [25]. This form is found in particular in younger women and appears to be associated with viral infection (in up to 20\%) [26-28]. Less frequent etiologic factors are Parkinson's disease, amyloid, tumors (paraneoplastic gastroparesis), scleroderma, or mesenteric ischemia [29]. Importantly, medication-induced gastroparesis has to be considered in all patients. Typically here are opioids, ciclosporine, anticholinergics and glucagon-like peptide 1 (GLP1)-agonists [30-32]. The latter should be particularly suspected in diabetic patients before considering the gastroparesis to be caused by diabetes and poor control of blood glucose. From a clinical perspective, the simplest classification of gastroparesis is into the two categories diabetic vs. non-diabetic. Delayed gastric emptying can be observed in $28 \%$ to $65 \%$ of unselected patients with diabetes [33,34]. Patients with type 1 diabetes have a higher incidence of gastroparesis as compared with type $2(5.25 \mathrm{vs.} 1 \%)$ and an earlier age at onset $[7,9,29]$. Type 2 diabetics, however, have more serious symptoms. Gastroparesis in diabetic patients usually occurs 10 years after the onset of diabetes and it parallels other forms of diabetic microvascular disease, including neuropathy and retinopathy. Severe symptoms of diabetic gastroparesis cause poor glycemic control and poor nutritional status, and increase the risk of hypoglycaemia [35].

Gastroparesis is often a debilitating disease associated with significant morbidity and mortality [36,37]. The most frequently reported symptoms are: early satiety, postprandial fullness, nausea-vomiting, bloating and upper abdominal pain [38]. The latter is somewhat neglected by physicians, but appear to occur in up to $72 \%-90 \%$ of patients. Pain is often experienced after meals $(72 \%)$, but can also occur during night time $(74 \%)$ [29,39]. The presence of non-prandial abdominal pain can, therefore, not be used to rule out the diagnosis. It rather appears to be another piece in the wide presentation of the disease. Weight loss is not a typical feature of gastroparesis patients. Symptoms can vary depending on the specific etiology. Nausea, at least, is similar in all patients with gastroparesis, irrespectively of the underlying cause. Both nausea and vomiting significantly correlate with a reduced quality of life [40]. It should be kept in mind that the presence of symptoms is a sine qua non for the diagnosis of gastroparesis.

\subsection{Dumping Syndrome}

In early dumping syndrome, rapid transition of food into the small intestine results in a fluid shift (due to hyperosmolarity) and release of gastrointestinal hormones such as vasoactive substances (neurostatin, vasoactive intestinal peptide (VIP), incretins (gastric inhibitory polypeptide (GIP), GLP1) and glucose-modulators (insulin, glucagon) $[2,15,41-43]$. This results in gastrointestinal and vasomotor symptoms; the latter is characterized by hypotension (due to the above mentioned fluid shift) and a consecutive sympathetic nerve system response [15,16]. In late dumping, rapid absorption of glucose (due to the presence of undigested carbohydrates in the small intestine) increases incretin release (GLP1), which exaggerates insulin response [2,44-46]. This ultimately leads to hypoglycaemia within 1 to $3 \mathrm{~h}$ after meal intake (so called incretin-driven hyperinsulinemic response) [15,16]. Although these mechanisms are typically and frequently seen as a postsurgical complication, dumping can also occur in the absence of previous surgery [47]. While in these cases, there is no alteration in gastric anatomy, gastric emptying is accelerated due to a disturbed intrinsic gastric innervation [2]. Diabetes is the main contributor $[47,48]$. Thus, diabetes can be associated with both delayed (see gastroparesis) and increased gastric emptying. The latter is particularly seen in early diabetes and more so in type 2 than 1 . Due to overlapping symptoms, it might be difficult to distinguish gastroparesis from dumping 
syndrome in diabetic patients. Vomiting makes gastroparesis more probable, while dumping should be considered in particular in the presence of diarrhea [49]. Idiopathic forms of dumping have been described also. Similarly to gastroparesis, viral infections are a possible cause [50]. About $50 \%$ of patients with idiopathic dumping syndrome report a history of gastroenteritis symptoms [50].

Symptoms of early and late dumping are quite different. Early dumping includes the following symptoms that occur within $1 \mathrm{~h}$, typically $30 \mathrm{~min}$ after a meal ingestion [15]: abdominal pain, bloating, borborygmi, nausea, diarrhea (gastrointestinal symptoms); and fatigue, desire to lie down, flushing, palpitations/perspiration, tachycardia, hypotension and rarely syncope (vasomotor symptoms). For late dumping, typical symptoms can be divided into neuroglycopenia and autonomic reactivity [17]. While the first group comprises fatigue, weakness, confusion, hunger and syncope, the latter includes perspiration, palpitations, tremor and irritability. Dumping syndrome can result in significant weight loss (30\%) and considerably affects quality of life [51]. It may lead to hospitalizations due to hypoglycemia, episodes of confusion, seizures and even epilepsy [52].

Table 1. Symptoms and causes of gastroparesis.

Symptoms and Causes of Gastroparesis
Symptoms:
Postprandial fullness, early satiety, bloating, abdominal distension, nausea, and vomiting, abdominal pain,
and dysphagia
Causes:
Diabetes
Non-diabetic causes
Surgery (such as gastrectomy with vagotomy, vagal nerve injury, Roux-en-Y, pancreatectomy, anti-reflux
operations, lung transplant)
Gastrointestinal disorders: gastroesophageal reflux, gastric ulcer disease, gastritis, atrophic gastritis,
pancreatitis
Diseases of the nervous system (such as parkinsonism)
Connective tissue diseases (such as scleroderma)
Unknown ("idiopathic gastroparesis")
Paraneoplastic
Mesenteric ischemia
Viral infections: e.g., CMV
Side effect of medications
Metabolic and endocrine disorders: hypothyroidism, pregnancy, uremia

Table 2. Symptoms and causes of dumping syndrome.

Symptoms and Causes of Dumping Syndrome
Symptoms:
Early dumping syndrome (within $1 \mathrm{~h}$ after meal ingestion)
Gastrointestinal symptoms: Abdominal pain, epigastric fullness, diarrhea, nausea, vomiting, borborygmi,
and bloating
Vasomotor symptoms: desire to lie down, palpitations and tachycardia, fatigue, faintness, syncope,
perspiration, headache, light-headedness, hypotension, flushing, and pallor
Late dumping syndrome (1-3 h after meal ingestion)
Neuroglycopenia: fatigue, weakness, confusion, hunger and syncope
Autonomic reactivity: perspiration, palpitations, tremor and irritability
Causes:
Surgery: gastrojejunostomy, antrectomy, pylorectomy, pyloroplasty, esophagectomy, vagotomy, Roux-en Y
bypass, Nissen fundoplication
Not-surgery related: diabetes mellitus, viral illness, unkown (“idiopathic”)




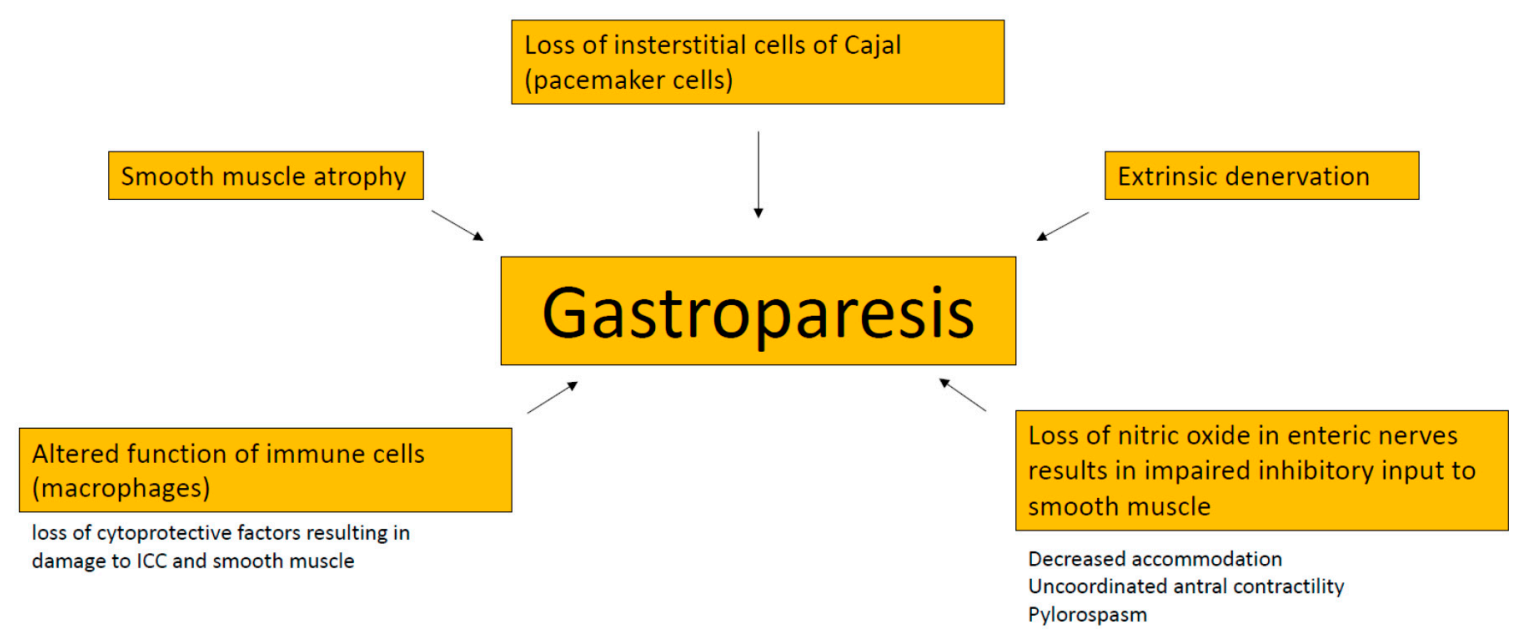

Figure 1. Pathophysiology of gastroparesis. ICC, interstitial cells of Cajal.

\section{Diagnostic Evaluations}

Gastroparesis and dumping syndrome have to be distinguished from several organic and functional diseases. Distinction between irritable bowel syndrome, functional dyspepsia and gastroparesis, dumping syndrome might be particularly difficult $[29,53]$. Many cardinal symptoms are shared between these entities. Diagnostic evaluations are therefore key to clearly establish the diagnosis of gastroparesis and dumping syndrome [54].

\subsection{Gastroparesis}

Gastroparesis is diagnosed by a thorough history and physical examination, which help to identify the presence of characteristic symptoms of gastroparesis and exclude alternative diagnoses. Once the syndrome is suspected, an upper endoscopy is necessary to rule out mechanical gastric obstruction. Although an upper gastrointestinal series may suggest the diagnosis, there is a limited role for imaging in the workup for gastroparesis and delayed emptying should be confirmed by gastric transit testing such as gastric scintigraphy, breath testing, and wireless motility capsule $[55,56]$. Gastroparesis is diagnosed if typical symptoms are present, a delayed gastric emptying is documented and a correlation of symptoms with food intake is observed [29]. This definition of gastroparesis highlights two key points: (1) objective measures of delayed gastric emptying are needed to establish the diagnosis; and (2) symptoms are a sine-qua-non [29]. A test that is positive for delayed gastric emptying does not make the diagnosis if a patient is asymptomatic. Scintigraphy is the gold-standard to establish decreased gastric emptying and the most widely used technique. However, there are regional differences. Some European centers use breath tests more often because there are simply to handle and have been shown to correlate nicely with scintigraphy results [57]: A test meal (usually white bread, butter, water and an egg omelette with 13C octanoic acid) is ingested and 13C measured using expired breath gas analysis [58]. Magnetic resonance imaging (MRI) assesses gastric physiology by simultaneously measuring gastric emptying and motility without the need of ionizing radiation [59]. There is increasing evidence that MRI is a reliable non-invasive tool in the diagnostic evaluation of gastroparesis [59]. Given the importance of disrupted ICC networks in the pathophysiology of gastroparesis, slow wave measurements are another potential diagnostic test. In fact, a combination of electrogastrogram and magnetogastrogram is able to distinguish gastroparesis patients from controls [60].

\subsection{Dumping Syndrome}

Increased pre-test probability such as a past surgical history and the presence of typical symptoms result in a high clinical suspicion for the presence of dumping syndrome. Two questionnaires have been 
established for the identification of clinically relevant symptoms of dumping syndrome, the Sigstad's score and the Arts' dumping questionnaire [2,51]. A simple visual analogue scale might also be used [61]. Objective measurements are less established compared to gastroparesis. Measuring glucose has a low diagnostic yield, but might be considered when symptoms of late dumping syndrome are present [2]. Importantly, glucose should be measured in the plasma and not in the capillary blood, since low glucose levels are less reliable in the latter. Suggested cut-offs are 2.8 and $3.3 \mathrm{mmol} / \mathrm{L}$ [62]. Provocation tests might have higher predictive values. Two options are available, oral glucose tolerance test (OGTT) and the mixed meal tolerance test $[2,63]$. For OGTT, 50 or $75 \mathrm{~g}$ sugar is ingested and blood glucose, haematocrit, pulse and blood pressure are measured every $30 \mathrm{~min}$ for $3 \mathrm{~h} \mathrm{[15].} \mathrm{An} \mathrm{increase} \mathrm{in}$ the haematocrit by $3 \%$ and/or pulse acceleration by 10 min suggest early dumping syndrome, while development of hypoglycemia suggests late dumping syndrome [15]. In the mixed meal tolerance test, carbohydrates, fats and proteins are ingested, and glucose, insulin are checked every $30 \mathrm{~min}[44,64]$. The ordering physician should keep in mind that even healthy individuals can show a drop in their blood sugar levels after meal intake and that therefore the test has a high false positive rate [65]. Gastric emptying studies are potential alternatives, but their specificity and sensitivity is rather low [2].

\section{Treatment of Gastroparesis}

Treatment strategies are quite similar in gastroparesis and dumping syndrome. In a multidisciplinary setting, a step-wise approach should be followed, where dietary modifications and patient education represent the first step, pharmacological interventions the second, and surgical interventions the last option (Figure 2). In the acute setting of gastroparesis, dehydration and electrolyte abnormalities should be corrected by oral or intravenous routes, as appropriate [66]. In severe cases, gastric decompression by insertion of a nasogastric tube might be necessary [29]. In a more chronic setting, the first step in the management of gastroparesis are nutritional counselling and dietary modifications. The patient should be educated to eat small, low-fat, low-fibre meals [29]. Counselling by a nutritional expert is of paramount importance, because gastroparesis can lead to considerable malnutrition due to inadequate oral intake and vomiting $[67,68]$. In case of underlying diabetes, controlling blood glucose levels should be aimed for [29]. Epidemiological studies have linked poor diabetes control with gastroparesis [69]. As of yet, there are no randomized controlled trials proving that lowering $\mathrm{HbA} 1 \mathrm{c}$ indeed improves gastroparesis symptoms. Nonetheless, controlling diabetes makes sense for numerous reasons. When these initial steps do not lead to clinical improvement, pharmacological interventions are needed. The armamentarium is limited, but at least a few drugs are available [70]. Among those are the prokinetics metoclopramide and domperidone that act as dopamine 2 receptor antagonists. Their efficacy has been demonstrated in several randomized trials [71,72]. However, their efficacy appears to be independent of their potential for accelerating gastric emptying, since gastric emptying has been shown to poorly correlate with symptomatic response [73]. Other mechanisms such as affecting gastric hypersensivity or gastric accommodation may be responsible for their effect [74]. Data about their long-term effects are sparse, and several potentially deleterious side-effects limit their use in clinical practice. Metoclopramide imposes a risk for tardive dyskinesia in $1 \%$ of patients, while domperidone has been linked to serious cardiac side-effects. Use of metoclopramide should, therefore, be restricted to a maximum of 3 months, at the lowest possible dose [75]. Erythromycin, a macrolide antibiotic, improves gastric emptying through stimulating the motilin receptor and represents an option for short-term treatment, when metoclopramide and domperidone have failed [76]. Nausea, a frequent and bothersome symptom in gastroparesis, can be treated with antiemetics such as prochlorperazine, diphenhydramine, or a 5-HT3 antagonist [66]. Aprepitant can also be considered given its effects on nausea, vomiting and overall symptoms in gastroparesis patients [77]. Iberogast, an over-the-counter herbal preparation is frequently used in functional dyspepsia. Despite having no effect on gastric emptying, iberogast has been shown to positively affect gastroparesis symptoms in a placebo-controlled crossover trial [78]. Several interventional approaches have been developed and hyped in the past with different outcomes. 
The injection of botulinum toxin during upper endoscopy into the pyloric muscle might be effective, albeit only in the short term [79-82]. However, the two only randomized controlled trials failed to show efficacy of pyloric botox $[83,84]$. Whether this was due to small sample size and consecutive lack of power has yet to be determined. Another therapy option is gastric electrical stimulation (GES), where electric current is delivered to gastric smooth muscles via implanted electrodes with a positive impact on gastroparesis symptoms and gastric emptying [85]. GES has been proposed as an alternative for patients with intractable gastroparesis, but a double-blind controlled trial showed only minor improvement with a significant complication rate [86]. A meta-analysis, including 10 studies, suggested that diabetic gastroparesis patients seem to benefit the most, whereas idiopathic gastroparesis patients and postsurgical patients are less responsive and need further research [87]. Another technique, the gastric peroral endoscopic pyloromyotomy (G-POEM) showed some efficacy in gastroparesis patients but further studies are needed [88-93]. Esoflip is currently the newest kid on the block. It is a balloon catheter that was developed for dilations in the gastrointestinal tract. Non-controlled studies revealed high rates of technical success with increased distensibility and symptomatic improvement after pyloric dialation [94]. Esoflip might have its role in difficult to treat patients before considering surgical interventions, but more data, particularly randomized controlled trials are needed first. Surgery should be seen as treatment of last resort and should be discussed individually in a multidisciplinary team setting due to the sparse clinical data. At least, a recent case series including 28 patients suggested improvement of symptoms, gastric emptying and a consecutive reduction in the need for prokinetic treatment 3 months after surgery [95]. However, surgery clearly has its role when oral nutritional intake is compromised. In these cases, jejunostomy feeding should be considered. A percutaneous or surgical placement of a gastrostomy-jejunostomy tube enables decompression of the stomach and permits enteral feeding [96].

\section{Gastroparesis}

\begin{tabular}{|c|}
\hline $\begin{array}{l}\text { Dietary modifications and patient counselling } \\
\text { Small, low-fat, low-fibre meals }\end{array}$ \\
\hline Glucose control if diabetes \\
\hline $\begin{array}{l}\text { Pharmacological interventions } \\
\text { Procinetics (Metoclopramid and Domperidone) } \\
\text { Erythromycin } \\
\text { Consider Iberogast and anti-emetics }\end{array}$ \\
\hline $\begin{array}{l}\text { Invasive interventions } \\
\text { - Botox, Esoflip } \\
\text { - } \text { GES } \\
\text { - } \text { G-POEM or surgical pyloroplasty }\end{array}$ \\
\hline
\end{tabular}

\section{Dumping syndrome}

Dietary modifications and patient counselling Small, high-fibre, high-protein meals

\section{Dietary supplements}

Pharmacological interventions

Acarbose

Somatostatin analogues

Consider anti-emetics and anti-diarrheals

\section{Invasive interventions \\ - Gastric bypass reversal \\ Gastric pouch restriction \\ Pancreatic resection}

Consider jejunostomy feeding if malnourished patient with inadequate oral intake

Figure 2. Treatment algorithm for gastroparesis and dumping syndrome. GES, gastric electrical stimulation; G-POEM, gastric peroral endoscopic pyloromyotomy.

\section{Treatment of Dumping Syndrome}

Similarly to gastroparesis, dietary modifications and patient education by a nutritional expert are the first steps in the treatment of dumping syndrome [2,97-100]. Smaller and more frequent meals (around six per day) are recommended [2]. Intake of fluids should be delayed by at least $30 \mathrm{~min}$. Rapidly absorbable carbohydrates and alcoholic beverages should be avoided, while intake of high-fibre, high-protein food is recommended [2]. The rationale behind is that liquids further 
accelerate gastric emptying. Lying down after a meal for $30 \mathrm{~min}$ may further delay emptying of the stomach $[15,101]$. As a second step, dietary supplements such as guar gum, pectin or glucomannan can be added to enhance food viscosity [102-104]. However, most patients do not tolerate these agents due to frequent side-effects such as gas formation and bloating [2]. Pharmacological interventions are the third step in the therapeutic ladder. However, it should be kept in mind that as of yet no treatment has been approved for dumping syndrome. The currently available options are (1) acarbose and (2) for severe cases somatostatin analogues. Acarbose is an alpha-glucosidase inhibitor that decreases intraluminal digestion of carbohydrates in the duodenum. Therefore, it is used to treat postprandial hypoglycemia in late dumping syndrome [105-108]. However, as seen for the dietary supplements, acarbose is associated with side-effects such as flatulence occurring in a high proportion of patients [109]. Somatostatin analogues can improve dumping syndrome by affecting several disease mechanisms: (i) delaying gastric emptying; (ii) slowering small intestine transit; (iii) decreasing release of gastrointestinal hormones including insulin secretion; and (iv) inhibition of postprandial vasodilation [2,51]. Somatostatin analogues such as octreotide can be applied either subcutaneously three times a day or intramuscularly every 2 to 4 weeks [51,110-112]. The latter is probably preferred by the majority of patients. Most important side-effects are steatorrhea, diarrhea, nausea, gallstone formation, pain at injection site and weight gain. Due to these side-effects daily applied doses should start as low as $25 \mathrm{mcg}$ and then titrated up to a maximum of $100 \mathrm{mcg}$. Treatment should be stopped after 2 weeks (subcutaneous application) or 2 months (intramuscular application) if no improvement is observed [2]. Non-specific symptoms such as nausea and diarrhea may be symptomatically treated with antiemetics (meclizine, promethazine) and antidiarrheals (tincture of opium, loperamide). Anticholinergics like dicyclomine, hyoscyamine, and propantheline slow gastric emptying and are antispasmotic. Diazoxide is a potassium channel activator, which influences hypoglycaemia and is used in late dumping [113]. However, these drugs have been studied in only few patients with dumping syndrome. As for gastroparesis, surgical interventions (revision surgery) should be discussed on a case to case basis, since data for their efficacy are limited [2].

\section{Conclusions}

Gastroparesis and dumping syndrome are frequent disorders, particularly in diabetic and postsurgical patients. Since symptoms are non-specific, these two entities have to be distinguished from several differential diagnoses and require objective measures that document delayed or accelerated gastric emptying. A multidisciplinary team approach including nutritional experts, endocrinologists and gastroenterologists is key to success. Within this setting, optimal treatment strategies can be discussed and individually tailored to each patient. This is particularly important in cases that are difficult to treat, where possible treatment options are limited and data for their efficacy conflicting.

Author Contributions: Conceptualization, S.R.V. and T.G.; methodology, S.R.V. and T.G.; writing-original draft preparation, S.R.V. and T.G.; writing—review and editing, S.R.V. and T.G.; visualization, T.G.; supervision, S.R.V. and T.G.; project administration, S.R.V.

Conflicts of Interest: T.G. has a consulting contract with Sanofi-Aventis, received a travel grant from Falk Pharma $\mathrm{GmbH}$ and Vifor, and an unrestricted research grant from Novartis. S.R.V. received consultant fees and unrestricted research grants from Abbott, Ferring, MSD, Pfizer, Takeda, Tillots, UCB, Vifor and Falk Pharma GmbH.

\section{References}

1. Camilleri, M.; Bharucha, A.E.; Farrugia, G. Epidemiology, mechanisms, and management of diabetic gastroparesis. Clin. Gastroenterol. Hepatol. 2011, 9, 5-12. [CrossRef] [PubMed]

2. van Beek, A.P.; Emous, M.; Laville, M.; Tack, J. Dumping syndrome after esophageal, gastric or bariatric surgery: Pathophysiology, diagnosis, and management. Obes. Rev. 2017, 18, 68-85. [CrossRef] [PubMed]

3. Talley, N.J.; Vakil, N.B.; Moayyedi, P. American gastroenterological association technical review on the evaluation of dyspepsia. Gastroenterology 2005, 129, 1756-1780. [CrossRef] [PubMed] 
4. Mulla, C.M.; Storino, A.; Yee, E.U.; Lautz, D.; Sawnhey, M.S.; Moser, A.J.; Patti, M.E. Insulinoma After Bariatric Surgery: Diagnostic Dilemma and Therapeutic Approaches. Obes. Surg. 2016, 26, 874-881. [CrossRef] [PubMed]

5. Mathur, A.; Gorden, P.; Libutti, S.K. Insulinoma. Surg. Clin. N. Am. 2009, 89, 1105-1121. [CrossRef] [PubMed]

6. Bharucha, A.E. Epidemiology and natural history of gastroparesis. Gastroenterol. Clin. N. Am. 2015, 44, 9-19. [CrossRef] [PubMed]

7. Jung, H.K.; Choung, R.S.; Locke, G.R.; Schleck, C.D.; Zinsmeister, A.R.; Szarka, L.A.; Mullan, B.; Talley, N.J. The incidence, prevalence, and outcomes of patients with gastroparesis in Olmsted County, Minnesota, from 1996 to 2006. Gastroenterology 2009, 136, 1225-1233. [CrossRef] [PubMed]

8. Rey, E.; Choung, R.S.; Schleck, C.D.; Zinsmeister, A.R.; Talley, N.J.; Locke, G.R. Prevalence of hidden gastroparesis in the community: The gastroparesis "iceberg". J. Neurogastroenterol. Motil. 2012, 18, 34-42. [CrossRef]

9. Choung, R.S.; Locke, G.R.; Schleck, C.D.; Zinsmeister, A.R.; Melton, L.J.; Talley, N.J. Risk of gastroparesis in subjects with type 1 and 2 diabetes in the general population. Am. J. Gastroenterol. 2012, 107, 82-88. [CrossRef]

10. Horowitz, M.; Harding, P.E.; Maddox, A.F.; Wishart, J.M.; Akkermans, L.M.; Chatterton, B.E.; Shearman, D.J. Gastric and oesophageal emptying in patients with type 2 (non-insulin-dependent) diabetes mellitus. Diabetologia 1989, 32, 151-159. [CrossRef]

11. Horowitz, M.; Maddox, A.F.; Wishart, J.M.; Harding, P.E.; Chatterton, B.E.; Shearman, D.J. Relationships between oesophageal transit and solid and liquid gastric emptying in diabetes mellitus. Eur. J. Nucl. Med. 1991, 18, 229-234. [CrossRef] [PubMed]

12. Dong, K.; Yu, X.J.; Li, B.; Wen, E.G.; Xiong, W.; Guan, Q.L. Advances in mechanisms of postsurgical gastroparesis syndrome and its diagnosis and treatment. Chin. J. Dig. Dis. 2006, 7, 76-82. [CrossRef] [PubMed]

13. Dong, K.; Li, B.; Guan, Q.L.; Huang, T. Analysis of multiple factors of postsurgical gastroparesis syndrome after pancreaticoduodenectomy and cryotherapy for pancreatic cancer. World J. Gastroenterol. 2004, 10, 2434-2438. [CrossRef] [PubMed]

14. Nusrat, S.; Bielefeldt, K. Gastroparesis on the rise: Incidence vs awareness? Neurogastroenterol. Motil. 2013, 25, 16-22. [CrossRef] [PubMed]

15. Tack, J.; Arts, J.; Caenepeel, P.; De Wulf, D.; Bisschops, R. Pathophysiology, diagnosis and management of postoperative dumping syndrome. Nat. Rev. Gastroenterol. Hepatol. 2009, 6, 583-590. [CrossRef]

16. Tack, J.; Deloose, E. Complications of bariatric surgery: Dumping syndrome, reflux and vitamin deficiencies. Best Pract. Res. Clin. Gastroenterol. 2014, 28,741-749. [CrossRef] [PubMed]

17. Eagon, J.C.; Miedema, B.W.; Kelly, K.A. Postgastrectomy syndromes. Surg. Clin. N. Am. 1992, 72, 445-465. [CrossRef]

18. Vecht, J.; Masclee, A.A.; Lamers, C.B. The dumping syndrome. Current insights into pathophysiology, diagnosis and treatment. Scand. J. Gastroenterol. Suppl. 1997, 223, 21-27.

19. McLarty, A.J.; Deschamps, C.; Trastek, V.F.; Allen, M.S.; Pairolero, P.C.; Harmsen, W.S. Esophageal resection for cancer of the esophagus: Long-term function and quality of life. Ann. Thorac. Surg. 1997, 63, 1568-1572. [CrossRef]

20. Banerjee, A.; Ding, Y.; Mikami, D.J.; Needleman, B.J. The role of dumping syndrome in weight loss after gastric bypass surgery. Surg. Endosc. 2013, 27, 1573-1578. [CrossRef]

21. Papamargaritis, D.; Koukoulis, G.; Sioka, E.; Zachari, E.; Bargiota, A.; Zacharoulis, D.; Tzovaras, G. Dumping symptoms and incidence of hypoglycaemia after provocation test at 6 and 12 months after laparoscopic sleeve gastrectomy. Obes. Surg. 2012, 22, 1600-1606. [CrossRef] [PubMed]

22. Tzovaras, G.; Papamargaritis, D.; Sioka, E.; Zachari, E.; Baloyiannis, I.; Zacharoulis, D.; Koukoulis, G. Symptoms suggestive of dumping syndrome after provocation in patients after laparoscopic sleeve gastrectomy. Obes. Surg. 2012, 22, 23-28. [CrossRef] [PubMed]

23. Berg, P.; McCallum, R. Dumping Syndrome: A Review of the Current Concepts of Pathophysiology, Diagnosis, and Treatment. Dig. Dis. Sci. 2016, 61, 11-18. [CrossRef]

24. O'Grady, G.; Angeli, T.R.; Du, P.; Lahr, C.; Lammers, W.J.E.P.; Windsor, J.A.; Abell, T.L.; Farrugia, G.; Pullan, A.J.; Cheng, L.K. Abnormal initiation and conduction of slow-wave activity in gastroparesis, defined by high-resolution electrical mapping. Gastroenterology 2012, 143, 589-598.e583. [CrossRef] [PubMed] 
25. Hyett, B.; Martinez, F.J.; Gill, B.M.; Mehra, S.; Lembo, A.; Kelly, C.P.; Leffler, D.A. Delayed radionucleotide gastric emptying studies predict morbidity in diabetics with symptoms of gastroparesis. Gastroenterology 2009, 137, 445-452. [CrossRef] [PubMed]

26. Chen, J.D.; Lin, Z.; Pan, J.; McCallum, R.W. Abnormal gastric myoelectrical activity and delayed gastric emptying in patients with symptoms suggestive of gastroparesis. Dig. Dis. Sci. 1996, 41, 1538-1545. [CrossRef] [PubMed]

27. Oh, J.J.; Kim, C.H. Gastroparesis after a presumed viral illness: Clinical and laboratory features and natural history. Mayo Clin. Proc. 1990, 65, 636-642. [CrossRef]

28. Bityutskiy, L.P.; Soykan, I.; McCallum, R.W. Viral gastroparesis: A subgroup of idiopathic gastroparesis-clinical characteristics and long-term outcomes. Am. J. Gastroenterol. 1997, 92, 1501-1504.

29. Camilleri, M.; Parkman, H.P.; Shafi, M.A.; Abell, T.L.; Gerson, L. Clinical guideline: Management of gastroparesis. Am. J. Gastroenterol. 2013, 108, 18-37. [CrossRef]

30. Mittal, R.K.; Frank, E.B.; Lange, R.C.; McCallum, R.W. Effects of morphine and naloxone on esophageal motility and gastric emptying in man. Dig. Dis. Sci. 1986, 31, 936-942. [CrossRef]

31. Salehi, M.; Aulinger, B.A.; D'Alessio, D.A. Targeting beta-cell mass in type 2 diabetes: Promise and limitations of new drugs based on incretins. Endocr. Rev. 2008, 29, 367-379. [CrossRef] [PubMed]

32. Maes, B.D.; Vanwalleghem, J.; Kuypers, D.; Ghoos, Y.; Rutgeerts, P.J.; Vanrenterghem, Y.F. Differences in gastric motor activity in renal transplant recipients treated with FK-506 versus cyclosporine. Transplantation 1999, 68, 1482-1485. [CrossRef] [PubMed]

33. Samsom, M.; Vermeijden, J.R.; Smout, A.J.; Van Doorn, E.; Roelofs, J.; Van Dam, P.S.; Martens, E.P.; Eelkman-Rooda, S.J.; Van Berge-Henegouwen, G.P. Prevalence of delayed gastric emptying in diabetic patients and relationship to dyspeptic symptoms: A prospective study in unselected diabetic patients. Diabetes Care 2003, 26, 3116-3122. [CrossRef]

34. Jones, K.L.; Russo, A.; Stevens, J.E.; Wishart, J.M.; Berry, M.K.; Horowitz, M. Predictors of delayed gastric emptying in diabetes. Diabetes Care 2001, 24, 1264-1269. [CrossRef] [PubMed]

35. Horváth, V.J.; Izbéki, F.; Lengyel, C.; Kempler, P.; Várkonyi, T. Diabetic gastroparesis: Functional/morphologic background, diagnosis, and treatment options. Curr. Diabetes Rep. 2014, 14, 527. [CrossRef] [PubMed]

36. Woodhouse, S.; Hebbard, G.; Knowles, S.R. Psychological controversies in gastroparesis: A systematic review. World J. Gastroenterol. 2017, 23, 1298-1309. [CrossRef] [PubMed]

37. Bielefeldt, K. Gastroparesis: Concepts, controversies, and challenges. Scientifica (Cairo) 2012, 2012, 424802. [CrossRef]

38. Liu, N.; Abell, T. Gastroparesis Updates on Pathogenesis and Management. Gut Liver 2017, 11, 579-589. [CrossRef]

39. Cherian, D.; Sachdeva, P.; Fisher, R.S.; Parkman, H.P. Abdominal pain is a frequent symptom of gastroparesis. Clin. Gastroenterol. Hepatol. 2010, 8, 676-681. [CrossRef]

40. Cherian, D.; Parkman, H.P. Nausea and vomiting in diabetic and idiopathic gastroparesis. Neurogastroenterol. Motil. 2012, 24, 217-222. [CrossRef]

41. Tack, J. Gastric motor disorders. Best Pract. Res. Clin. Gastroenterol. 2007, 21, 633-644. [CrossRef] [PubMed]

42. Mayer, E.A.; Thompson, J.B.; Jehn, D.; Reedy, T.; Elashoff, J.; Meyer, J.H. Gastric emptying and sieving of solid food and pancreatic and biliary secretion after solid meals in patients with truncal vagotomy and antrectomy. Gastroenterology 1982, 83 Pt 2, 184-192.

43. Lawaetz, O.; Blackburn, A.M.; Bloom, S.R.; Aritas, Y.; Ralphs, D.N. Gut hormone profile and gastric emptying in the dumping syndrome. A hypothesis concerning the pathogenesis. Scand. J. Gastroenterol. 1983, 18, 73-80. [CrossRef] [PubMed]

44. Salehi, M.; Gastaldelli, A.; D'Alessio, D.A. Blockade of glucagon-like peptide 1 receptor corrects postprandial hypoglycemia after gastric bypass. Gastroenterology 2014, 146, 669-680. [CrossRef] [PubMed]

45. Toft-Nielsen, M.; Madsbad, S.; Holst, J.J. Exaggerated secretion of glucagon-like peptide-1 (GLP-1) could cause reactive hypoglycaemia. Diabetologia 1998, 41, 1180-1186. [CrossRef] [PubMed]

46. Eloy, R.; Garaud, J.C.; Moody, A.; Jaeck, D.; Grenier, J.F. Jejunal factor stimulating insulin release in the isolated perfused canine pancreas and jejunum. Horm. Metab. Res. 1975, 7, 461-467. [CrossRef]

47. Mehagnoul-Schipper, D.J.; Lenders, J.W.; Willemsen, J.J.; Hopman, W.P. Sympathoadrenal activation and the dumping syndrome after gastric surgery. Clin. Auton. Res. 2000, 10, 301-308. [CrossRef] 
48. Holdsworth, C.D.; Turner, D.; McIntyre, N. Pathophysiology of post-gastrectomy hypoglycaemia. Br. Med. J. 1969, 4, 257-259. [CrossRef]

49. Hejazi, R.A.; Patil, H.; McCallum, R.W. Dumping syndrome: Establishing criteria for diagnosis and identifying new etiologies. Dig. Dis. Sci. 2010, 55, 117-123. [CrossRef]

50. Berg, P.; McCallum, R.; Hall, M.; Sarosiek, I. Dumping Syndrome: Updated Perspectives on Etiologies and Diagnosis. Pract. Gastroenterol. 2014, 38, 30-38.

51. Arts, J.; Caenepeel, P.; Bisschops, R.; Dewulf, D.; Holvoet, L.; Piessevaux, H.; Bourgeois, S.; Sifrim, D.; Janssens, J.; Tack, J. Efficacy of the long-acting repeatable formulation of the somatostatin analogue octreotide in postoperative dumping. Clin. Gastroenterol. Hepatol. 2009, 7, 432-437. [CrossRef] [PubMed]

52. Marsk, R.; Jonas, E.; Rasmussen, F.; Näslund, E. Nationwide cohort study of post-gastric bypass hypoglycaemia including 5,040 patients undergoing surgery for obesity in 1986-2006 in Sweden. Diabetologia 2010, 53, 2307-2311. [CrossRef] [PubMed]

53. Tack, J.; Bisschops, R.; Sarnelli, G. Pathophysiology and treatment of functional dyspepsia. Gastroenterology 2004, 127, 1239-1255. [CrossRef] [PubMed]

54. Bredenoord, A.J.; Chial, H.J.; Camilleri, M.; Mullan, B.P.; Murray, J.A. Gastric accommodation and emptying in evaluation of patients with upper gastrointestinal symptoms. Clin. Gastroenterol. Hepatol. 2003, 1, $264-272$. [CrossRef]

55. Abell, T.L.; Camilleri, M.; Donohoe, K.; Hasler, W.L.; Lin, H.C.; Maurer, A.H.; McCallum, R.W.; Nowak, T.; Nusynowitz, M.L.; Parman, H.P.; et al. Consensus recommendations for gastric emptying scintigraphy: A joint report of the American Neurogastroenterology and Motility Society and the Society of Nuclear Medicine. Am. J. Gastroenterol. 2008, 103, 753-763. [CrossRef] [PubMed]

56. Tougas, G.; Eaker, E.Y.; Abell, T.L.; Abrahamsson, H.; Boivin, M.; Chen, J.; Hocking, M.P.; Quigley, E.M.; Koch, K.L.; Tokayer, A.Z.; et al. Assessment of gastric emptying using a low fat meal: Establishment of international control values. Am. J. Gastroenterol. 2000, 95, 1456-1462. [CrossRef] [PubMed]

57. Keller, J.; Bassotti, G.; Clarke, J.; Dinning, P.; Fox, M.; Grover, M.; Hellström, P.M.; Ke, M.; Layer, P.; Malagelada, C.; et al. Expert consensus document: Advances in the diagnosis and classification of gastric and intestinal motility disorders. Nat. Rev. Gastroenterol. Hepatol. 2018, 15, 291-308. [CrossRef]

58. Camilleri, M. Clinical practice. Diabetic gastroparesis. N. Engl. J. Med. 2007, 356, 820-829. [CrossRef]

59. de Zwart, I.M.; de Roos, A. MRI for the evaluation of gastric physiology. Eur. Radiol. 2010, 20, $2609-2616$. [CrossRef]

60. Bradshaw, L.A.; Cheng, L.K.; Chung, E.; Obioha, C.B.; Erickson, J.C.; Gorman, B.L.; Somarajan, S.; Richars, W.O. Diabetic gastroparesis alters the biomagnetic signature of the gastric slow wave. Neurogastroenterol. Motil. 2016, 28, 837-848. [CrossRef]

61. Mine, S.; Sano, T.; Tsutsumi, K.; Murakami, Y.; Ehara, K.; Saka, M.; Hara, K.; Fukagawa, T.; Udagawa, H.; Katai, H. Large-scale investigation into dumping syndrome after gastrectomy for gastric cancer. J. Am. Coll. Surg. 2010, 211, 628-636. [CrossRef] [PubMed]

62. Ritz, P.; Hanaire, H. Post-bypass hypoglycaemia: A review of current findings. Diabetes Metab. 2011, 37, 274-281. [CrossRef] [PubMed]

63. van der Kleij, F.G.; Vecht, J.; Lamers, C.B.; Masclee, A.A. Diagnostic value of dumping provocation in patients after gastric surgery. Scand. J. Gastroenterol. 1996, 31, 1162-1166. [CrossRef] [PubMed]

64. Khoo, C.M.; Muehlbauer, M.J.; Stevens, R.D.; Pamuklar, Z.; Chen, J.; Newgard, C.B.; Torquati, A. Postprandial metabolite profiles reveal differential nutrient handling after bariatric surgery compared with matched caloric restriction. Ann. Surg. 2014, 259, 687-693. [CrossRef] [PubMed]

65. Emous, M.; Ubels, F.L.; van Beek, A.P. Diagnostic tools for post-gastric bypass hypoglycaemia. Obes. Rev. 2015, 16, 843-856. [CrossRef] [PubMed]

66. Waseem, S.; Moshiree, B.; Draganov, P.V. Gastroparesis: Current diagnostic challenges and management considerations. World J. Gastroenterol. 2009, 15, 25-37. [CrossRef]

67. Ogorek, C.P.; Davidson, L.; Fisher, R.S.; Krevsky, B. Idiopathic gastroparesis is associated with a multiplicity of severe dietary deficiencies. Am. J. Gastroenterol. 1991, 86, 423-428.

68. Parkman, H.P.; Yates, K.P.; Hasler, W.L.; Nguyan, L.; Pasricha, P.J.; Snape, W.J.; Farrugia, G.; Calles, J.; Koch, K.L.; Abell, T.L.; et al. Dietary intake and nutritional deficiencies in patients with diabetic or idiopathic gastroparesis. Gastroenterology 2011, 141, 486-498. [CrossRef] 
69. Bytzer, P.; Talley, N.J.; Hammer, J.; Young, L.J.; Jones, M.P.; Horowitz, M. GI symptoms in diabetes mellitus are associated with both poor glycemic control and diabetic complications. Am. J. Gastroenterol. 2002, 97, 604-611. [CrossRef]

70. Quigley, E.M. Pharmacotherapy of gastroparesis. Expert Opin. Pharmacother. 2000, 1, 881-887. [CrossRef]

71. Patterson, D.; Abell, T.; Rothstein, R.; Koch, K.; Barnett, J. A double-blind multicenter comparison of domperidone and metoclopramide in the treatment of diabetic patients with symptoms of gastroparesis. Am. J. Gastroenterol. 1999, 94, 1230-1234. [PubMed]

72. McCallum, R.W.; Ricci, D.A.; Rakatansky, H.; Behar, J.; Rhodes, J.B.; Salen, G.; Deren, J.; Ippoliti, A.; Olsen, H.W.; Falchuk, K.; et al. A multicenter placebo-controlled clinical trial of oral metoclopramide in diabetic gastroparesis. Diabetes Care 1983, 6, 463-467. [CrossRef] [PubMed]

73. Janssen, P.; Harris, M.S.; Jones, M.; Masaoka, T.; Farre, R.; Törnblom, H.; Van Oudenhove, L.; Simren, M.; Tack, J. The relation between symptom improvement and gastric emptying in the treatment of diabetic and idiopathic gastroparesis. Am. J. Gastroenterol. 2013, 108, 1382-1391. [CrossRef] [PubMed]

74. Stanghellini, V.; Tack, J. Gastroparesis: Separate entity or just a part of dyspepsia? Gut 2014, 63, $1972-1978$. [CrossRef] [PubMed]

75. Rao, A.S.; Camilleri, M. Review article: Metoclopramide and tardive dyskinesia. Aliment. Pharmacol. Ther. 2010, 31, 11-19. [CrossRef] [PubMed]

76. Richards, R.D.; Davenport, K.; McCallum, R.W. The treatment of idiopathic and diabetic gastroparesis with acute intravenous and chronic oral erythromycin. Am. J. Gastroenterol. 1993, 88, 203-207. [PubMed]

77. Pasricha, P.J.; Yates, K.P.; Sarosiek, I.; McCallum, R.W.; Abell, T.L.; Koch, K.L.; Nguyen, L.A.B.; Snape, W.J.; Hasler, W.L.; Clarke, J.O.; et al. Aprepitant Has Mixed Effects on Nausea and Reduces Other Symptoms in Patients With Gastroparesis and Related Disorders. Gastroenterology 2018, 154, 65-76. [CrossRef] [PubMed]

78. Braden, B.; Caspary, W.; Börner, N.; Vinson, B.; Schneider, A.R. Clinical effects of STW 5 (Iberogast) are not based on acceleration of gastric emptying in patients with functional dyspepsia and gastroparesis. Neurogastroenterol. Motil. 2009, 21, 632-638. [CrossRef] [PubMed]

79. Friedenberg, F.; Gollamudi, S.; Parkman, H.P. The use of botulinum toxin for the treatment of gastrointestinal motility disorders. Dig. Dis. Sci. 2004, 49, 165-175. [CrossRef] [PubMed]

80. Ezzeddine, D.; Jit, R.; Katz, N.; Gopalswamy, N.; Bhutani, M.S. Pyloric injection of botulinum toxin for treatment of diabetic gastroparesis. Gastrointest. Endosc. 2002, 55, 920-923. [CrossRef] [PubMed]

81. Lacy, B.E.; Zayat, E.N.; Crowell, M.D.; Schuster, M.M. Botulinum toxin for the treatment of gastroparesis: A preliminary report. Am. J. Gastroenterol. 2002, 97, 1548-1552. [CrossRef] [PubMed]

82. Miller, L.S.; Szych, G.A.; Kantor, S.B.; Bromer, M.Q.; Knight, L.C.; Maurer, A.H.; Fisher, R.S.; Parkman, H.P. Treatment of idiopathic gastroparesis with injection of botulinum toxin into the pyloric sphincter muscle. Am. J. Gastroenterol. 2002, 97, 1653-1660. [CrossRef] [PubMed]

83. Arts, J.; Holvoet, L.; Caenepeel, P.; Bisschops, R.; Sifrim, D.; Verbeke, K.; Janssens, J.; Tack, J. Clinical trial: A randomized-controlled crossover study of intrapyloric injection of botulinum toxin in gastroparesis. Aliment. Pharmacol. Ther. 2007, 26, 1251-1258. [CrossRef] [PubMed]

84. Friedenberg, F.K.; Palit, A.; Parkman, H.P.; Hanlon, A.; Nelson, D.B. Botulinum toxin A for the treatment of delayed gastric emptying. Am. J. Gastroenterol. 2008, 103, 416-423. [CrossRef] [PubMed]

85. Angeli, T.R.; Du, P.; Midgley, D.; Paskaranandavadivel, N.; Sathar, S.; Lahr, C.; Abell, T.L.; Cheng, L.K.; O'Grady, G. Acute Slow Wave Responses to High-Frequency Gastric Electrical Stimulation in Patients With Gastroparesis Defined by High-Resolution Mapping. Neuromodulation 2016, 19, 864-871. [CrossRef] [PubMed]

86. Abell, T.; McCallum, R.; Hocking, M.; Koch, K.; Abrahamsson, H.; Leblanc, I.; Lindberg, G.; Konturek, J.; Nowak, T.; Quigley, E.M.; et al. Gastric electrical stimulation for medically refractory gastroparesis. Gastroenterology 2003, 125, 421-428. [CrossRef]

87. Chu, H.; Lin, Z.; Zhong, L.; McCallum, R.W.; Hou, X. Treatment of high-frequency gastric electrical stimulation for gastroparesis. J. Gastroenterol. Hepatol. 2012, 27, 1017-1026. [CrossRef]

88. Khashab, M.A.; Ngamruengphong, S.; Carr-Locke, D.; Bapaye, A.; Benias, P.C.; Serouya, S.; Dorwat, S.; Chaves, D.M.; Artifon, E.; de Moura, E.G.; et al. Gastric per-oral endoscopic myotomy for refractory gastroparesis: Results from the first multicenter study on endoscopic pyloromyotomy (with video). Gastrointest. Endosc. 2017, 85, 123-128. [CrossRef] 
89. Khashab, M.A.; Stein, E.; Clarke, J.O.; Saxena, P.; Kumbhari, V.; Chander Roland, B.; Kalloo, A.N.; Stavropoulos, S.; Pasricha, P.; Inoue, H. Gastric peroral endoscopic myotomy for refractory gastroparesis: First human endoscopic pyloromyotomy (with video). Gastrointest. Endosc. 2013, 78, 764-768. [CrossRef]

90. Dacha, S.; Mekaroonkamol, P.; Li, L.; Shahnavaz, N.; Sakaria, S.; Keilin, S.; Willingham, F.; Christie, J.; Cai, Q. Outcomes and quality-of-life assessment after gastric per-oral endoscopic pyloromyotomy (with video). Gastrointest. Endosc. 2017, 86, 282-289. [CrossRef]

91. Gonzalez, J.M.; Benezech, A.; Vitton, V.; Barthet, M. G-POEM with antro-pyloromyotomy for the treatment of refractory gastroparesis: Mid-term follow-up and factors predicting outcome. Aliment. Pharmacol. Ther. 2017, 46, 364-370. [CrossRef] [PubMed]

92. Gonzalez, J.M.; Lestelle, V.; Benezech, A.; Cohen, J.; Vitton, V.; Grimaud, J.C.; Barthet, M. Gastric per-oral endoscopic myotomy with antropyloromyotomy in the treatment of refractory gastroparesis: Clinical experience with follow-up and scintigraphic evaluation (with video). Gastrointest. Endosc. 2017, 85, 132-139. [CrossRef] [PubMed]

93. Rodriguez, J.H.; Haskins, I.N.; Strong, A.T.; Plescia, R.L.; Allemang, M.T.; Butler, R.S.; Cline, M.S.; El-Hayek, K.; Ponsky, J.L.; Kroh, M.D. Per oral endoscopic pyloromyotomy for refractory gastroparesis: Initial results from a single institution. Surg. Endosc. 2017, 31, 5381-5388. [CrossRef] [PubMed]

94. Gourcerol, G.; Tissier, F.; Melchior, C.; Touchais, J.Y.; Huet, E.; Prevost, G.; Leroi, A.M.; Ducrotte, P. Impaired fasting pyloric compliance in gastroparesis and the therapeutic response to pyloric dilatation. Aliment. Pharmacol. Ther. 2015, 41, 360-367. [CrossRef]

95. Hibbard, M.L.; Dunst, C.M.; Swanström, L.L. Laparoscopic and endoscopic pyloroplasty for gastroparesis results in sustained symptom improvement. J. Gastrointest. Surg. 2011, 15, 1513-1519. [CrossRef]

96. Felsher, J.; Chand, B.; Ponsky, J. Decompressive percutaneous endoscopic gastrostomy in nonmalignant disease. Am. J. Surg. 2004, 187, 254-256. [CrossRef]

97. Pittman, A.C.; Robinson, F.W. Dietary management of the "dumping" syndrome. Long-term follow-up. J. Am. Diet. Assoc. 1962, 40, 108-110.

98. Robinson, F.W.; Pittman, A.C. Dietary management of postgastrectomy dumping syndrome. Surg. Gynecol. Obstet. 1957, 104, 529-534.

99. Khoshoo, V.; Reifen, R.M.; Gold, B.D.; Sherman, P.M.; Pencharz, P.B. Nutritional manipulation in the management of dumping syndrome. Arch. Dis. Child. 1991, 66, 1447-1448. [CrossRef]

100. Kellogg, T.A.; Bantle, J.P.; Leslie, D.B.; Redmond, J.B.; Slusarek, B.; Swan, T.; Buchwald, H.; Ikramuddin, S. Postgastric bypass hyperinsulinemic hypoglycemia syndrome: Characterization and response to a modified diet. Surg. Obes. Relat. Dis. 2008, 4, 492-499. [CrossRef]

101. Ukleja, A. Dumping syndrome: Pathophysiology and treatment. Nutr. Clin. Pract. 2005, 20, 517-525. [CrossRef] [PubMed]

102. Jenkins, D.J.; Gassull, M.A.; Leeds, A.R.; Metz, G.; Dilawari, J.B.; Slavin, B.; Blendis, L.M. Effect of dietary fiber on complications of gastric surgery: Prevention of postprandial hypoglycemia by pectin. Gastroenterology 1977, 73, 215-217. [CrossRef]

103. Harju, E.; Larmi, T.K. Efficacy of guar gum in preventing the dumping syndrome. JPEN J. Parenter. Enter. Nutr. 1983, 7, 470-472. [CrossRef] [PubMed]

104. Kneepkens, C.M.; Fernandes, J.; Vonk, R.J. Dumping syndrome in children. Diagnosis and effect of glucomannan on glucose tolerance and absorption. Acta Paediatr. Scand. 1988, 77, 279-286. [CrossRef] [PubMed]

105. Ng, D.D.; Ferry, R.J.; Kelly, A.; Weinzimer, S.A.; Stanley, C.A.; Katz, L.E. Acarbose treatment of postprandial hypoglycemia in children after Nissen fundoplication. J. Pediatr. 2001, 139, 877-879. [CrossRef] [PubMed]

106. Ritz, P.; Vaurs, C.; Bertrand, M.; Anduze, Y.; Guillaume, E.; Hanaire, H. Usefulness of acarbose and dietary modifications to limit glycemic variability following Roux-en-Y gastric bypass as assessed by continuous glucose monitoring. Diabetes Technol. Ther. 2012, 14, 736-740. [CrossRef] [PubMed]

107. Speth, P.A.; Jansen, J.B.; Lamers, C.B. Effect of acarbose, pectin, a combination of acarbose with pectin, and placebo on postprandial reactive hypoglycaemia after gastric surgery. Gut 1983, 24, 798-802. [CrossRef] [PubMed]

108. McLoughlin, J.C.; Buchanan, K.D.; Alam, M.J. A glycoside-hydrolase inhibitor in treatment of dumping syndrome. Lancet 1979, 2, 603-605. [CrossRef] 
109. Hasegawa, T.; Yoneda, M.; Nakamura, K.; Ohnishi, K.; Harada, H.; Kyouda, T.; Yoshida, Y.; Makino, I. Long-term effect of alpha-glucosidase inhibitor on late dumping syndrome. J. Gastroenterol. Hepatol. 1998, 13, 1201-1206. [CrossRef] [PubMed]

110. Didden, P.; Penning, C.; Masclee, A.A. Octreotide therapy in dumping syndrome: Analysis of long-term results. Aliment. Pharmacol. Ther. 2006, 24, 1367-1375. [CrossRef] [PubMed]

111. Penning, C.; Vecht, J.; Masclee, A.A. Efficacy of depot long-acting release octreotide therapy in severe dumping syndrome. Aliment. Pharmacol. Ther. 2005, 22, 963-969. [CrossRef] [PubMed]

112. Deloose, E.; Bisschops, R.; Holvoet, L.; Arts, J.; De Wulf, D.; Caenepeel, P.; Lannoo, M.; Vanuytsel, T.; Andrews, C.; Tack, J. A pilot study of the effects of the somatostatin analog pasireotide in postoperative dumping syndrome. Neurogastroenterol. Motil. 2014, 26, 803-809. [CrossRef] [PubMed]

113. Vilarrasa, N.; Goday, A.; Rubio, M.A.; Caixas, A.; Pellitero, S.; Ciudin, A.; Calanas, A.; Botella, J.I.; Breton, I.; Morales, M.J.; et al. Hyperinsulinemic Hypoglycemia after Bariatric Surgery: Diagnosis and Management Experience from a Spanish Multicenter Registry. Obes. Facts 2016, 9, 41-51. [CrossRef] [PubMed]

(C) 2019 by the authors. Licensee MDPI, Basel, Switzerland. This article is an open access article distributed under the terms and conditions of the Creative Commons Attribution (CC BY) license (http://creativecommons.org/licenses/by/4.0/). 